\title{
Effects of tree control method, seed addition, and introduced mammal exclusion on seedling establishment in an invasive Pinus contorta forest
}

\author{
Kate G. McAlpine ${ }^{1 *}$, Clayson J. Howel1 ${ }^{1}$ and Debra M. Wotton ${ }^{1,2,3}$ \\ ${ }^{1}$ Department of Conservation, PO Box 10420, Wellington 6143, New Zealand \\ ${ }^{2}$ Present address: Moa's Ark Research, PO Box 11270, Wellington 6142, New Zealand \\ ${ }^{3}$ University of Canterbury, Private Bag 4800, Christchurch 8140, New Zealand \\ *Author for correspondence (Email: kmcalpine@doc.govt.nz)
}

Published online: 11 March 2016

\begin{abstract}
Pinus contorta is a widespread and ecologically damaging invasive tree in the southern hemisphere. Land managers want control methods that limit reinvasion by $P$. contorta and promote the recovery of native plant communities and ecosystem functions. Recovery of native vegetation may be slow if native seed supply is limited and/or introduced mammals destroy seeds and seedlings. We investigated how tree control method (felling or poisoning), seed addition, and exclusion of introduced mammals affected subsequent seedling establishment in montane stands of invasive $P$. contorta. Tree control method had a significant effect on seedling establishment: felling trees promoted establishment of $P$. contorta seedlings, whereas poisoning trees favoured establishment of native seedlings (provided seeds were available). Native seedling establishment was higher where seeds were sown, indicating native seed limitation at these sites. Excluding introduced mammals increased $P$. contorta seedling establishment, but did not have a significant effect on native seedling establishment. Our results indicate that poisoning $P$. contorta is a better management approach than felling where native seedling establishment is the desired outcome, and that this outcome can be enhanced by sowing native seed.
\end{abstract}

Keywords: alien species; biological invasions; wilding pines; pest mammal; seedling recruitment; restoration; succession

\section{Introduction}

Invasive trees have substantial impacts on biodiversity and ecosystem function in many regions of the world (Froude 2011; Richardson et al. 2014). Impacts can include changes to native biodiversity, hydrology, fire regime, nutrient cycling, and successional processes (Lamarque et al. 2011; van Wilgen \& Richardson 2012; Dickie et al. 2014), and reductions in the utility and value of agricultural and recreational land (Froude 2011). Despite a growing understanding of tree invasion impacts, the long-term outcomes for invaded sites are often unclear. Invasive trees that establish into naturally treeless environments can be particularly detrimental to native vegetation and ecosystem processes, and in some cases these effects are irreversible (Rundle et al. 2014). On the other hand, invasive trees can sometimes provide ecosystem benefits in areas where the native vegetation has been cleared by humans - i.e. in 'unnaturally' treeless environments. For example, studies from New Zealand and elsewhere have documented a diverse, abundant native subcanopy within stands of non-native trees (Ashton et al. 2014 (Sri Lanka); Brockerhoff et al. 2003 (New Zealand); Geldenhuys 1997 (South Africa); Lemenih et al. 2004 (Ethiopia)). In some situations, native plants recruit naturally if native seeds are present and environmental conditions are suitable. In other cases, native recruitment can be facilitated by management intervention, such as sowing seeds or planting seedlings. Several studies have examined the potential for non-native plantation forests to facilitate indigenous forest restoration (Zerbe 2002; Lemenih et al. 2004; Onaindia et al. 2013), and some authors have suggested that non-native forests might even be completely replaced by native plant succession under some circumstances (Williams 2011; Geldenhuys 2013; Wotton \& McAlpine 2013).
The method of invasive tree control can affect subsequent establishment of native and invasive plants. Felling invasive trees and planting native species can help to restore native vegetation to an invaded site (e.g. Ashton et al. 1997), but this is labour intensive, costly, and has no guarantee of success (Kettenring \& Adams 2001). The removal of established trees increases light availability at the soil surface, which tends to favour colonisation by light demanding species (Bazzaz 1979). Where native plants are poor competitors against invasive species, the early colonisers following this type of control can be exotic, invasive species - often including reinvasion by the species being controlled (D'Antonio \& Meyerson 2002; McAlpine et al. 2009; Ostertag et al. 2009). Control methods that minimise canopy disturbance, for example by leaving dead trees standing, can be more conducive to the establishment of native plants that have a competitive advantage in the shade (Loh \& Daehler 2007; Funk \& McDaniel 2009; Paul \& Ledgard 2009).

Native seedling establishment following invasive tree control may be reduced if herbivorous (or omnivorous) introduced mammals are present (Spear \& Chown 2009; Overdyck et al. 2013). Introduced mammals can also have beneficial effects on native vegetation, such as dispersing native seed (Williams et al. 2000; Shiels 2011) or suppressing invasive plant establishment (Zavaleta et al. 2001; Kessler 2002), but in general their effects are detrimental (Vázquez 2002). Studies that examine the effects of controlling introduced mammals for conservation purposes commonly report an increase in native plant regeneration (e.g. Allen et al. 1994; Husheer \& Robertson 2005; Blick et al. 2008; Wright et al. 2012; Cole \& Litton 2014), although invasive plant species can increase in abundance too (Zavaleta et al. 2001). In New Zealand, common introduced mammals such as brushtail 
possums (Trichosurus vulpecula), red deer (Cervus elaphus), sika deer (Cervus nippon), goats (Capra hircus) and ship rats (Rattus rattus) can reduce native plant abundance and species diversity, alter native species composition, and restrict native seedling establishment (Wardle et al. 2001; Wilson et al. 2003; Adkins 2012).

Conifers, and particularly pines (species in the genus Pinus), are invasive in many southern hemisphere countries, having spread widely from planted populations (Richardson et al. 1994). Pinus contorta is one of the worst; it readily invades unforested areas and causes significant problems in many countries (Richardson \& Rejmánek 2004; Gundale et al. 2014). In New Zealand, $P$. contorta and other invasive conifers have established on more than 1 million hectares, which represents a significant management cost to both local and national government agencies (New Zealand Wilding Conifer Management Group 2014). Despite the scale of the problem, in many situations the long-term outcome of $P$. contorta invasion is uncertain. Pinus contorta seedlings are shade-intolerant, and do not establish within $P$. contorta forest in the absence of disturbance (Coates 2000). Conversely, a naturally established native subcanopy has been recorded in P. contorta forest in New Zealand (Howell \& McAlpine 2016), so it is conceivable that the generation of vegetation that follows the senescence of $P$. contorta could be predominantly native in some areas. Furthermore, development of a native subcanopy could potentially be facilitated by management actions, as has been achieved in populations of other invasive tree species both in New Zealand and elsewhere (Loh \& Daehler 2007; Paul \& Ledgard 2009). The objective of our study was to determine how two methods of controlling P. contorta affected subsequent native and $P$. contorta seedling regeneration in a New Zealand montane environment below the natural treeline. We hypothesised that felling $P$. contorta trees would favour regeneration of $P$. contorta over natives, whereas the partial shade conditions created by poisoning $P$. contorta trees would favour regeneration of natives over $P$. contorta. We also hypothesised that the rate of native regeneration following $P$. contorta control could be increased by adding native seed and excluding introduced mammals.

\section{Materials and methods}

\section{Site}

This study was established at two sites in large stands of $P$. contorta in the Kaweka Forest Park, North Island, New Zealand. The two sites were approximately $5 \mathrm{~km}$ apart; the Black Birch site was on the Black Birch ridge, c. $600 \mathrm{~m}$ north of geodetic trig station A8A8 (LINZ 2015), $1060 \mathrm{~m}$ a.s.l. (39.30 S, $176.44 \mathrm{E})$, and the Don Juan site was c. $50 \mathrm{~m}$ north of geodetic trig station A3R0 (LINZ 2015), c. $900 \mathrm{~m}$ a.s.1.(39.34 S, 176.47 E). Mean annual max-min temperatures are $5.6-15.3^{\circ} \mathrm{C}$ and mean annual precipitation is $1279 \mathrm{~mm}$. Pre-human vegetation at these sites comprised native forest, but seral grasslands became established due to fires induced by humans (Rogers 1994), soon after they arrived c. AD 1280 (Wilmshurst et al. 2008). Subsequent burning and conversion to farmland maintained an open vegetation of native grasses, mānuka (Leptospermum scoparium), scrub and bare soils (Elder 1959). Pinus contorta spread to the study sites from populations that were deliberately established in the 1960s to prevent soil erosion (Cunningham \& Roberts 1970). Both study sites are within $400 \mathrm{~m}$ of remnants ( $>5 \mathrm{ha}$ ) of native forest, dominated by mountain beech (Fuscospora cliffortioides) but including a mix of other native tree species such as F. fusca (red beech) and gymnosperms Phyllocladus alpinus and Podocarpus cunninghamii. Sika deer, red deer, brushtail possums, ship rats, pigs (Sus scrofa), goats, hares (Lepus europaeus occidentalis), rabbits (Oryctolagus cuniculus cuniculus), and house mice (Mus musculus) are likely to be present at both sites (Davidson \& Fraser 1991; King 2005).

Twelve 30-m diameter groups of trees were selected in 7-14 m high, closed-canopy $P$. contorta forest at both the Black Birch and Don Juan sites, giving a total of 24 groups. Each group was at least $20 \mathrm{~m}$ from any forest edge, tree fall gap, or other group.

\section{Pinus contorta treatments}

Treatments were randomly assigned: at each site, four patches of trees were felled, four patches were poisoned, and four patches were left untreated as experimental controls. One long-term aim of the research project was to test the effect of treatment area size on natural regeneration and growth of native plants (not reported here), so the area treated within each patch was either 'small' (diameter approximately equivalent to canopy height, 7-14 m) or 'large' (diameter approximately twice the canopy height, 14-28 m).

The poisoning treatment was done between September and December 2011. Individual trees were poisoned by applying $20 \%$ Triclopyr ester $600 \mathrm{~g} / \mathrm{L}\left(\mathrm{Grazon}^{\mathrm{TM}}\right)$ in diesel to the bark at the base of the tree, using a low-pressure spray gun. Cuts were made through the outer bark with a small axe and the trunk was fully covered (not dripping) from ground level upwards to a height equal to two times the trunk diameter. The felling treatment was done in March 2012. All trees within the treatment area were felled by chainsaw. Trees were cut below the lowest green needles, approximately $0.5 \mathrm{~m}$ to $1 \mathrm{~m}$ above the ground. For safety and accessibility reasons, trees were felled in the same direction (usually downhill) wherever possible.

Following $P$. contorta control treatments, eight $50 \times 50$ cm plots $\left(0.25 \mathrm{~m}^{2}\right)$ were established within each patch, giving a total of 192 plots across the two sites. In the poisoned and untreated patches, these $50 \times 50 \mathrm{~cm}$ plots were placed between larger $(2 \times 2 \mathrm{~m})$ plots established for a different experiment (not reported here). Each patch had four of these large plots, centred on north, south, west, and east axes, $3 \mathrm{~m}$ from the patch centre. For the current experiment, the eight $50 \times 50 \mathrm{~cm}$ plots were placed in flat or gently sloping areas clear of standing or felled trunks, approximately $2-3 \mathrm{~m}$ from the patch centre and evenly distributed between the large plots. In felled patches, pine slash up to $2 \mathrm{~m}$ deep made plot placement difficult. In most felled patches, plots were located 2-4 m from the patch centre, but in two felled patches some plots were as much as $7 \mathrm{~m}$ from patch centre. Proximity of plots to pine slash was variable, but most plots would have been shaded by nearby pine slash at some point of each day. In each patch, the eight plots were randomly allocated one of four combinations of seed sowing and cage treatments (two plots per combination): no seed, no cage; no seed, with cage; with seed, no cage; with seed, with cage.

\section{Seed sowing}

Seeds of $P$. contorta and three native species were collected from adult plants within the Kaweka Forest Park in May 2012. We chose native species that were naturally present in the area 
and capable of establishing beneath a forest canopy: dry-fruited Fuscospora fusca (red beech) and F. cliffortioides (mountain beech), and fleshy-fruited Coprosma grandifolia (large-leaved coprosma). These species are all palatable to herbivores (Allen et al. 1984; Husheer et al. 2003), as is P. contorta (Ledgard \& Norton 2008). Fruit flesh was manually removed from C. grandifolia seeds. Seeds of all species were stored at room temperature in dry paper bags for 2 weeks before sowing in May 2012. Seeds were sown directly onto the undisturbed soil/ leaf litter surface of plots allocated the seed sowing treatment. The number of seeds sown per plot varied according to seed availability: 100 for $P$. contorta, F. fusca, and F. cliffortioides, and 50 for $C$. grandifolia, making a total of 350 seeds sown per $50 \times 50 \mathrm{~cm}$ plot. In order to minimise seed displacement outside plot boundaries by water or gravity, seeds were sown onto the middle $30 \times 30 \mathrm{~cm}$ of the plot or, in sloping plots, closer to the upper edge of the plot. Seedlings (including those at the cotyledon stage) of the sown species were counted in May 2012, before seed sowing, then again in February 2014, 2 years after seed sowing.

\section{Exclusion of introduced mammals}

In order to exclude seed and seedling consumers, we constructed closed-top cages from $19 \mathrm{~mm}$ aperture, stainless steel welded mesh. We expected this mesh aperture to exclude most introduced mammals, excepting mice and small rats (unpubl. data, Tim Day, Xcluder ${ }^{\circledR}$ Pest Proof Fencing). Cages were $60 \mathrm{~cm}$ square and $30 \mathrm{~cm}$ high. In May 2012, after seeds had been sown, cages were pinned securely to the ground over plots allocated the cage treatment, using a minimum of eight $13-\mathrm{cm}$ galvanised steel pins per cage. Where necessary, the soil was lightly excavated around the plot edge to allow the cage edge to tightly fit ground contours. Pine needles readily fell through the mesh, so very little leaf litter accumulated on top of the cages.

\section{Effects of Pinus contorta treatments on canopy openness}

We predicted that our pine treatments would have significantly different effects on light availability, which in turn could influence seedling establishment. Canopy openness was used as an index of light availability. To quantify percentage canopy openness we took photographs of the forest canopy in February 2014, two years after $P$. contorta treatments. We used a Canon EOS 50D digital SLR camera and $4.5 \mathrm{~mm}$ Sigma EX DC hemispherical (fisheye) lens. Photographs were digitally analysed using HemiView image processing software to calculate the proportion of sky visible through the canopy (= canopy openness) (HemiView Forest Canopy Analysis System v8, Delta-T Devices, Cambridge, UK). Four photos were taken in each patch, approximately $3 \mathrm{~m}$ from the patch centre and $1 \mathrm{~m}$ above the ground, in north, south, east, and west directions. The canopy openness values from these four photos were then averaged to give a single value for each patch. This approach meant that the average canopy openness value assigned to a patch was not necessarily an accurate reflection of the canopy openness directly above any individual seed sowing plot in that patch - particularly in felled patches, where depth and proximity of pine slash was variable. However, this approach was deemed sufficient for our purposes, given the large expected difference in canopy openness between felled and non-felled treatments.

\section{Statistical analysis}

We tested whether pine treatment (untreated, poisoned or felled) had a significant effect on canopy openness. We fitted a beta regression model with variable precision using the betareg package (Cribari-Neto \& Zeileis 2010) in R 3.2.1 (R Core Team 2015). Beta regression is a relatively new statistical technique suitable for modelling continuous data restricted to values between zero and one, such as canopy openness (Korhonen et al. 2007).

We ran two analyses to test the effect of $P$. contorta treatment, seed sowing and caging on seedling presence and abundance: one for native seedlings (sown species only), and a second for $P$. contorta seedlings. We fitted generalised linear mixed-effects models (GLMMs) using the R package lme4 (Bates et al. 2014). Seedlings were absent from many plots, leading to zero-inflated abundance data. Therefore, we modelled seedling presence and abundance as a two-step process (Martin et al. 2005): 1) seedling presence in plots, and 2) seedling abundance in those plots where at least one seedling was present. Seedling presence was modelled as a binary response variable with a Bernoulli error distribution and a logit link function. Abundance-when-present (hereafter abundance) was modelled with a Poisson distribution and a log link function. We included 'pine treatment', 'seed sowing', 'cage', 'site' and 'patch size' as fixed effects, and 'patch' as a random effect in both models. Seedling abundance data were overdispersed (approximate overdispersion parameter $>1$, calculated as the ratio of the sum of squared Pearson residuals to the residual degrees of freedom), so we also included 'plot' as a random effect to model between-subject heterogeneity (Breslow 1984). We calculated marginal $R^{2}$ (variance explained by fixed effects only) and conditional $R^{2}$ (variance explained by both fixed and random effects) to determine the goodness of fit and amount of variance explained by seedling presence and abundance models (Nakagawa \& Schielzeth 2013).

\section{Results}

\section{Effects of Pinus contorta treatments on canopy openness}

Pinus contorta treatment had a significant effect on canopy openness $(\mathrm{z}=-18.85, P<0.0001)$. Trees in poisoned patches were still dying 2 years after treatment; most retained brown needles on at least some branches, and some (particularly bigger trees) still had green needles. Not surprisingly, percentage canopy openness was significantly greater in felled patches $(41.5 \pm 15.7 \%$, mean \pm s.d. $)$ than in untreated patches $(16.7 \pm$ $3.6 \% ; \mathrm{z}=5.64, P<0.0001)$. However, canopy openness did not differ significantly between untreated and poisoned (18.4 \pm $3.5 \%)$ patches $(\mathrm{z}=1.016, P=0.31)$. Pine treatment explained $64.7 \%$ of the variance in percent canopy openness. Canopy openness was most variable in felled patches because of the variability of depth and proximity of pine slash in relation to photo points (see Methods).

\section{Native seedlings}

Before seed sowing, there were ten seedlings of the native sown species (eight $C$. grandifolia and two $F$. fusca) present in five of the 192 plots. All native seedlings counted 2 years after sowing were beyond the cotyledon stage. Seed sowing had a greater effect than other experimental treatments on the presence of native seedlings in plots after 2 years $(\mathrm{n}=$ 192 plots, $\mathrm{z}=7.21, P<0.0001$; Fig. 1). Results of $\mathrm{z}$-tests 
were consistent with whether $95 \%$ confidence intervals on coefficients included zero. Native seedlings were largely absent from plots without seeds added (present in only $4 \%$ of plots, compared with $69 \%$ of plots with seeds added). Across all plots, adding seeds increased native seedling abundance 27 -fold (5.14, 0-34 seedlings; mean and range) compared with plots with no seeds added $(0.19,0-15)$. Pinus contorta treatment also had a significant effect on native seedling presence and abundance (Fig. 1). Native seedlings were less likely to be present in plots where $P$. contorta was felled (22\% of plots) than in untreated plots $(42 \% ; \mathrm{z}=-2.88, P=0.004$; Fig. 1$)$. Poisoning $P$. contorta significantly increased native seedling abundance in plots where at least one seedling was present (4.45, $0-34 ; \mathrm{n}=70$ plots, $\mathrm{z}=2.75, P=0.0059)$ compared with untreated plots $(1.88,0-16)$, but there was no significant difference between felled plots $(1.66,0-29)$ and untreated plots ( $\mathrm{z}=0.741, P=0.46$; Fig. 1$)$. Caging had no significant effect on native seedling presence $(\mathrm{z}=-1.340, P=0.18)$ or abundance $(3.4,0-34 ; \mathrm{z}=-1.080, P=0.28)$ compared with uncaged plots (1.9, 0-19; Fig. 1). Native seedlings were more abundant at Don Juan than Black Birch $(\mathrm{z}=3.14, P=0.0017$; Fig. 1). Fixed effects in the fitted model for native seedling presence explained $62 \%\left(\right.$ marginal $\left.R^{2}\right)$ of the variance in the data (conditional $R^{2}=0.69$ ). Fixed effects in the native seedling abundance model explained $26 \%\left(\right.$ marginal $\left.R^{2}\right)$ of the variance (conditional $R^{2}=0.31$ ).

\section{Pinus contorta seedlings}

Before seed sowing, there were five $P$. contorta seedlings present in three of the 192 plots, all at the cotyledon stage. Most $P$. contorta seedlings recorded 2 years after seed sowing were beyond the cotyledon stage, although some cotyledonstage seedlings were also recorded. Pinus contorta treatment and caging both influenced $P$. contorta seedling presence and abundance after 2 years (Fig. 2). When $P$. contorta trees were felled, $P$. contorta seedlings were more likely to be present (70\% compared with $9 \%$ of untreated plots; $\mathrm{n}=192$ plots, $\mathrm{z}$ $=5.565, P<0.0001)$ and were significantly more abundant $(6.20,0-71$, mean and range; $\mathrm{n}=64$ plots, $\mathrm{z}=2.92, P=0.003)$ than in untreated plots $(0.16,0-3$; Fig. 2$)$. Poisoning had no significant effect on $P$. contorta seedling presence $(\mathrm{z}=1.66$, $P=0.097)$ or abundance $(0.53,0-18 ; \mathrm{z}=0.651, P=0.51490)$ compared with untreated plots (Fig. 2). Caging significantly increased $P$. contorta seedling presence $(\mathrm{z}=-2.29, P=0.022)$ and abundance $(3.94,0-71 ; \mathrm{z}=-4.13, \mathrm{P}<0.0001)$ compared with uncaged plots $(0.66,0-9$; Fig. 2$)$. Seed sowing had no influence on $P$. contorta seedling presence $(\mathrm{z}=-0.78, P=0.43)$ or abundance $(2.5,0-71)$ compared with plots without seeds sown (2.1, 0-31; Fig. 2). Fixed effects in the fitted model for $P$. contorta seedling presence explained $43 \%$ of the variance in the data (conditional $R^{2}=0.43$ ). Fixed effects in the fitted model for $P$. contorta seedling abundance explained $45 \%$ of the variance in the data (conditional $R^{2}=0.46$ ).

\section{Discussion}

Our results demonstrate that the method used to control invasive trees can strongly influence the composition of subsequent seedling regeneration; poisoning $P$. contorta trees promoted the establishment of native seedlings (where seed was added), whereas felling trees promoted the establishment of $P$. contorta seedlings. Other studies have demonstrated that control methods that leave dead trees standing (e.g. poisoning, ring-barking) can facilitate native seedling establishment, particularly at sites with a nearby native seed

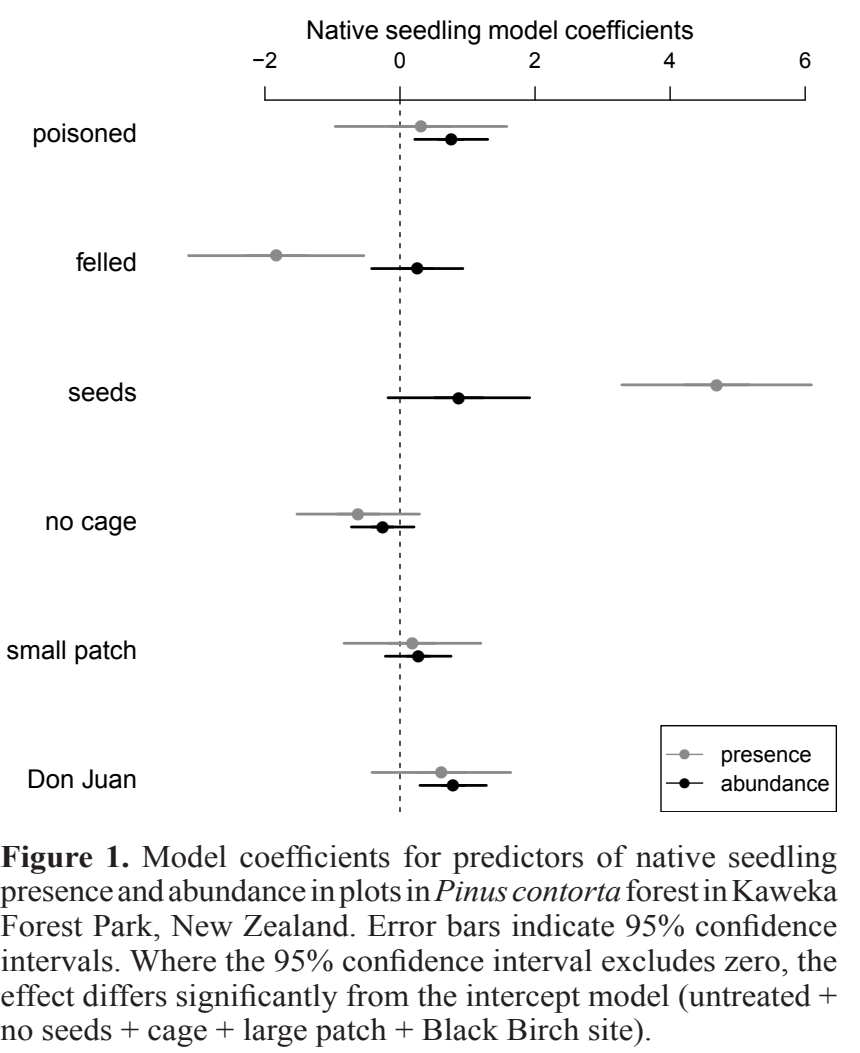

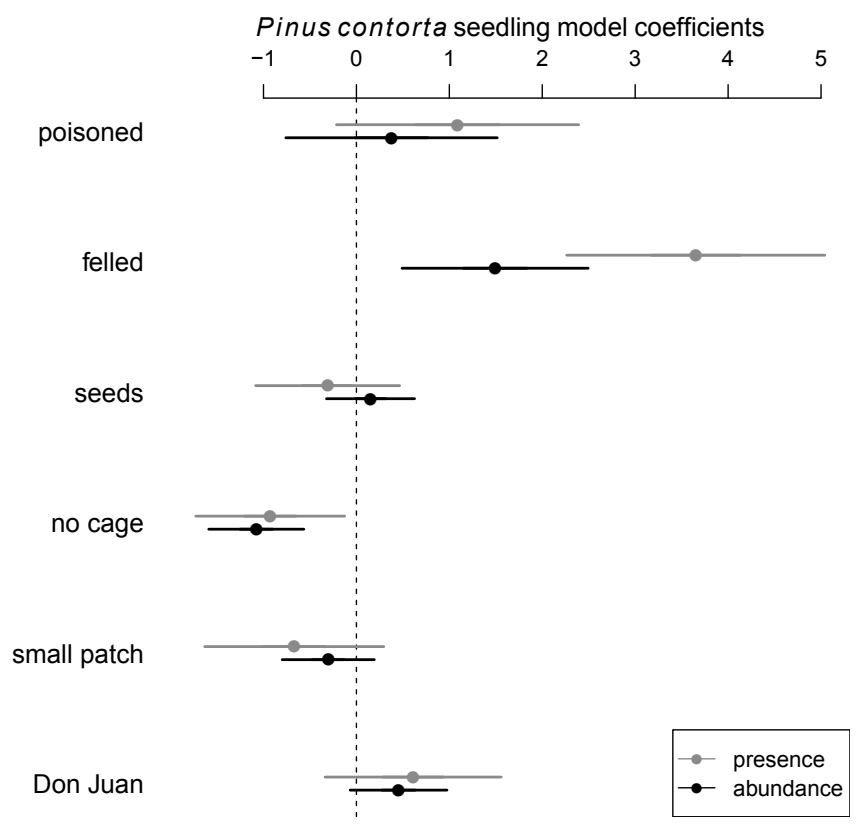

Figure 2. Model coefficients for predictors of Pinus contorta seedling presence and abundance in plots in P. contorta forest in Kaweka Forest Park, New Zealand. Error bars indicate 95\% confidence intervals. Where the $95 \%$ confidence interval excludes zero, the effect differs significantly from the intercept model (untreated + no seeds + cage + large patch + Black Birch site). 
source and sufficient rainfall (Wakibara \& Mnaya 2002; Loh \& Daehler 2008; Hughes et al. 2012). In a New Zealand study of vegetation succession following control of the congener $P$. radiata, the authors suggested that the shade of dead standing trees favoured regeneration of shade-tolerant native species, whereas the high light levels and soil disturbance created by felling $P$. radiata favoured the growth of $P$. radiata and other light-demanding non-native species (Paul \& Ledgard 2009). Differences in available light likely influenced our results too, given that average canopy openness in felled patches was more than double that of untreated and poisoned patches. Like $P$. radiata, $P$. contorta is light-demanding and does not establish in the shade, but regenerates strongly in high light conditions (Coates 2000). Pinus contorta seedling regeneration is likely to be even higher if $P$. contorta trees are removed after they are felled. Our treatments may have created other microclimatic differences that influenced our results; for example, soil and air temperatures may be more extreme and more variable in felled plots than in poisoned or untreated plots (Ritter et al. 2005; Latif \& Blackburn 2010). Felling P. contorta can also be associated with invasion by non-native grasses and herbs, due to belowground effects of $P$. contorta on soil biogeochemical cycling and mycorrhizal associations (Dickie et al. 2014). Regardless of the mechanisms driving our results, we can conclude that felling is not an efficient control method for $P$. contorta if the objective is to use a low intensity intervention to restore native vegetation. Additionally, the re-establishment of $P$. contorta seedlings after felling indicates that ongoing control is likely to be required for as long as the felling method is employed. Many studies on the control of other tree species come to the same conclusion (Kettenring \& Adams 2001; McAlpine et al. 2009), so this principle might be applicable to many species of light-demanding invasive trees.

The greater native seedling establishment in poisoned patches than in untreated patches could not be attributed to differences in light environment, because canopy openness was similar in poisoned and untreated patches. Alternative explanations include a decrease in below-ground competition and/or increase in soil moisture or nutrient availability following the death of canopy trees (Riegel et al. 1995). Despite uncertainty about the mechanisms underlying differences in native seedling numbers, our results suggest that poisoning $P$. contorta trees could facilitate native plant succession where native seeds are present. A naturally established subcanopy of almost 50 native species has previously been recorded in untreated $P$. contorta forest at our study sites, although it was unknown whether the natives established before or after $P$. contorta invasion (Howell \& McAlpine 2016). In the current study, there were also higher numbers of native seedlings at the Don Juan site compared with the Black Birch site. We were unable to explain this result, but there are likely to be a number of environmental differences between the sites, such as the difference in soil chemistry found in a previous study (Howell \& McAlpine 2016).

Control of invasive trees is not necessarily required to initiate native succession; many studies document native plant establishment in stands of untreated invasive trees (e.g. Rodriguez 2006; Williams 2011; Geldenhuys 2013).The likelihood of natives establishing from seed within a closed canopy $P$. contorta forest may increase as the $P$. contorta forest ages. This is because evenly-aged, closed-canopy, monospecific forests tend to self-thin (see Westoby 1984) as they age, which tends to result in an increase in canopy openness and thus in light availability for seedling establishment (Franklin et al.
2002). Poisoning $P$. contorta is likely to result in a similar gradual increase in light availability that may increase the rate of native seedling establishment. This change may take many years, given that some poisoned trees in our study retained brown, or even green, needles two years after treatment. In the long term, the dead $P$. contorta canopy will open up completely, as the dead trees collapse. Pinus contorta may re-establish at this point, depending on seed and light availability, and whether a shade-casting subcanopy has established in the interim (Wotton \& McAlpine 2013).

Establishment of beech and Coprosma grandifolia appears to be seed-limited at our study sites, as these seedlings were recorded in only four plots without seeds added. The distances (up to $400 \mathrm{~m}$ ) between our study sites and native seed sources likely limit the supply of seeds. Beech seed is dispersed by wind, but most falls within 10 m of the parent (Wardle 1984; Canham et al.2014). Although C. grandifolia seed is bird-dispersed, and thus potentially moved much further, adult trees were scarce in the area. Additionally, frugivorous birds tend to be uncommon in exotic forest in New Zealand (Wotton \& McAlpine 2015), so it is likely that few seeds of bird-dispersed species are being dispersed into the $P$. contorta forest. However, many species of native plants can survive in $P$. contorta forest (Howell \& McAlpine 2016) and establish if seeds are introduced. Our results indicate that sowing native seed into $P$. contorta forest can increase native seedling establishment, particularly if trees are controlled in a way that leaves dead trees standing. Seed addition of species with short-lived seed banks, in particular, may be required to restore native vegetation at sites isolated from seed sources.

Previous studies have demonstrated that introduced mammals can have significant negative impacts on native vegetation in New Zealand (Campbell \& Rudge 1984; Wardle et al. 2001; Wilson et al. 2003), but we did not detect a significant effect of mammal exclusion on native seedling presence or abundance in our study. It is possible that mice and small rats, which could access our cages, took some of the seeds sown on our plots. Interestingly, excluding mammals did result in higher numbers of $P$. contorta seedlings (in felled plots). Sika deer and red deer may be the main drivers of this effect, because they are common in the Kaweka Forest Park (Davidson \& Fraser 1991; Fraser et al. 2000), and are known from northern hemisphere studies to have negative impacts on the establishment, growth and survival of several Pinus species, including $P$. contorta (Gill 1992; Palmer \& Truscott 2003; Widenmaier \& Strong 2010). Other mammal species such as possums, pigs, goats, rabbits, hares and rodents may also consume $P$. contorta seedlings and/or seeds and reduce seedling establishment (Castro et al. 1999; Ledgard \& Norton 2008). Our results suggest a potential management conflict; reducing mammal numbers in order to improve native plant recruitment may also improve $P$. contorta recruitment under certain conditions. It is also possible that cages had additional positive impacts on $P$. contorta seedling survival, for example by providing partial shade and/or wind protection.

Non-native plant species can act as 'nurse' crops, ameliorating harsh environmental conditions, for example by providing shade or increasing soil nutrient availability, thereby increasing the rate of native plant establishment (Ewel \& Putz 2004; Yang et al. 2009). Examples include gorse (Ulex europaeus) and Scotch broom (Cytisus scoparius) in New Zealand (Wilson 1994; Burrows et al. 2015), and briar (Rosa rubiginosa) in Argentina (Svriz et al. 2013). Invasive conifers can increase nutrient availability and thus improve 
the quality of degraded high country (mostly $>600 \mathrm{~m}$ asl) soils in New Zealand (Davis 1998), which could in turn increase native plant establishment (Dyck 2004). Several studies have demonstrated that beech seedlings can survive in $P$. contorta forest (this study; Dehlin et al. 2008; Howell \& McAlpine 2016), so $P$. contorta could potentially act as a 'nurse' crop for beech. This may be particularly valuable in areas such as the Kawekas, where beech forest has been depleted due to past burning, clearing, and conversion to farmland (Elder 1959; Rogers 1994). Beech is typically slow to re-establish and many factors have been implicated in this phenomenon, including poor seed dispersal, mycorrhizal limitation, competition from exotic grasses, browsing by small animals and absence of microsites protected from water stress (Wardle 1984; Ledgard \& Davis 2004; Dickie et al. 2012 ). A return to beech-dominated forest through $P$. contorta would take a very long time, but it may be possible to speed up this process through addition of seed or seedlings, as has been suggested for native forest restoration under the ecologically similar congeners $P$. ponderosa in New Zealand (Forbes et al. 2015) and P. radiata in Spain (Onaindia et al. 2013) and Chile (Becerra \& Montenegro 2013).

\section{Acknowledgements}

This project was funded by the New Zealand Department of Conservation (Investigation 4155). Comments from Deb Wilson, James Griffiths, Susan Timmins, Clare Veltman, and two anonymous reviewers improved the manuscript. Jon Terry, James Griffiths, Nikolas Brocklehurst, Nick Fisentzidis, Thomas Ayley, David Burlace, Kaylyn Carpenter, Phil Bell, and Harry Thomas assisted with fieldwork.

\section{References}

Adkins NEH 2012. Vegetation assessment to understand the effect of feral goat populations on native flora composition. MSc. thesis, University of Canterbury. 83 p.

Allen R, Payton I, Knowlton J 1984. Effects of ungulates on structure and species composition in the Urewera forests as shown by exclosures. New Zealand Journal of Ecology 7: $119-130$

Allen RB, Lee WG, Rance BD 1994. Regeneration in indigenous forest after eradication of Norway rats, Breaksea Island, New Zealand. New Zealand Journal of Botany 32: 429-439.

Ashton MS, Gamage S, Gunatilleke IAUN, Gunatilleke CVS 1997. Restoration of a Sri Lankan rainforest: using Caribbean pine Pinus caribaea as a nurse for establishing late-successional tree species. Journal of Applied Ecology 34: 915-925.

Ashton MS, Gunatilleke CVS, Gunatilleke IAUN, Singhakumara BMP, Gamage S, Shibayama T, Tomimura C 2014. Restoration of rain forest beneath pine plantations: a relay floristic model with special application to tropical South Asia. Forest Ecology and Management 329: 351-359.

Bates D, Maechler M, Bolker B, Walker S 2014. lme4: Linear mixed-effects models using Eigen and S4. R package version 1.1-7.http://CRAN.R-project.org/package=lme4 (accessed 7 October 2015).
BazzazFA 1979. The physiological ecology of plant succession. Annual Review of Ecology and Systematics 10:351-371.

Becerra PI, Montenegro G 2013. The widely invasive tree Pinus radiata facilitates regeneration of native woody species in a semi-arid ecosystem. Applied Vegetation Science 16: 173-183.

Blick R, Bartholomew R, Burrell T, Burns KC 2008. Successional dynamics after pest eradication in the Karori Wildlife Sanctuary. New Zealand Natural Sciences 33: 3-14.

Breslow NE 1984. Extra-Poisson variation in log-linear models. Journal of the Royal Statistical Society. Series C, Applied Statistics 33: 38-44.

BrockerhoffEG, Ecroyd CE, LeckieAC, Kimberley MO 2003. Diversity and succession of adventive and indigenous vascular understorey plants in Pinus radiata plantation forests in New Zealand. Forest Ecology and Management 185: 307-326.

Burrows L, Cieraad E, Head N 2015. Scotch broom facilitates indigenous tree and shrub germination and establishment in dryland New Zealand. New Zealand Journal of Ecology 39: 61-70.

Campbell DJ, Rudge MR 1984. Vegetation changes induced over 10 years by goats and pigs at Port Ross, Auckland Islands (Subantarctic). New Zealand Journal of Ecology 7: 103-118.

Canham CD, Ruscoe WA, Wright EF, Wilson DJ 2014. Spatial and temporal variation in tree seed production and dispersal in a New Zealand temperate rainforest. Ecosphere 5: 1-14, Article 49.

Castro J, Gómez JM, García D, Zamora R, Hódar JA 1999. Seed predation and dispersal in relict Scots pine forests in southern Spain. Plant Ecology 145: 115-123.

Coates KD 2000. Conifer seedling response to northern temperate forest gaps. Forest Ecology and Management 127: 249-269.

Cole RJ, Litton CM 2014. Vegetation response to removal of non-native feral pigs from Hawaiian tropical montane wet forest. Biological Invasions 16: 125-140.

Cribari-Neto F, Zeileis A 2010. Beta regression in R. Journal of Statistical Software 34: 1-24. URL http://www.jstatsoft. org/v34/i02/ (accessed 7 October 2015).

Cunningham A, Roberts Q 1970. A provenance trial of Pinus contorta at 4,800 ft. in the Kaweka Range [New Zealand]. (Assessment after seven years.). New Zealand Journal of Forestry 15: 79-87.

D'Antonio C, Meyerson LA 2002. Exotic plant species as problems and solutions in ecological restoration: a synthesis. Restoration Ecology 10: 703-713.

Davidson M, Fraser K 1991. Official hunting patterns, and trends in the proportions of sika (Cervus nippon) and red deer (C. elaphus scoticus) in the Kaweka Range, New Zealand, 1958-1988. New Zealand Journal of Ecology 15: 31-40.

Davis M 1998. Soil impacts of afforestation in the high country. New Zealand Forestry 42: 34-38.

Dehlin H, Peltzer DA, Allison VJ, Yeates GW, Nilsson M, Wardle DA 2008. Tree seedling performance and belowground properties in stands of invasive and native tree species. New Zealand Journal of Ecology 32: 67-79.

Dickie IA, Davis M, Carswell FE 2012. Quantification of mycorrhizal limitation in beech spread. New Zealand Journal of Ecology 36: 210-215.

Dickie IA, St John MG, Yeates GW, Morse CW, Bonner KI, 
Orwin K, Peltzer DA 2014. Belowground legacies of Pinus contorta invasion and removal result in multiple mechanisms of invasional meltdown. AoB Plants 6: 1-15.

Dyck WJ 2004. A forestry industry view of wilding conifers and options for their control. In: Hill, RL, Zydenbos, SM, Bezar, CMeds Managing wilding conifers in New Zealand: present and future. Proceedings of a workshop held in conjunction with the annual conference of the New Zealand Plant Protection Society in Christchurch, August 2003. Christchurch, NZPPS. Pp. 41-44.

Elder NL 1959. Vegetation of the Kaweka Range. Transactions of the Royal Society of New Zealand 87: 9-26.

Ewel JJ, Putz FE 2004. A place for alien species in ecosystem restoration. Frontiers in Ecology and the Environment 2: 354-360.

Forbes A, Norton D, Carswell F 2015. Underplanting degraded exotic Pinus with indigenous conifers assists forest restoration. Ecological Management \& Restoration 16: 41-49.

Franklin JF, Spies TA, Pelt RV, Carey AB, Thornburgh DA, Berg DR, Lindenmayer DB, Harmon ME, Keeton WS, Shaw DC 2002. Disturbances and structural development of natural forest ecosystems with silvicultural implications, using Douglas-fir forests as an example. Forest Ecology and Management 155: 399-423.

Fraser K, Cone J, Whitford E2000. Arevision of the established ranges and new populations of 11 introduced ungulate species in New Zealand. Journal of the Royal Society of New Zealand 30: 419-437.

Froude VA 2011. Wilding conifers in New Zealand: Status report. Prepared for the Ministry of Agriculture and Forestry. Bay of Islands, New Zealand, Pacific Eco-Logic Ltd. 207 p.

Funk JL, McDaniel S 2009. Altering light availability to restore invaded forest: the predictive role of plant traits. Restoration Ecology 18: 865-872.

Geldenhuys CJ 1997. Native forest regeneration in pine and eucalypt plantation in Northern Province, South Africa. Forest Ecology and Management 99: 101-115.

Geldenhuys CJ 2013. Converting invasive alien plant stands to natural forest nature's way. In: Jose, S, Harminder, P, Batish, DR, Kohli, RK eds Invasive Plant Ecology. Boca Raton, FL, CRC Press. Pp. 217-237.

Gill RMA 1992. A review of damage by mammals in north temperate forests: 1. Deer. Forestry 65: 145-169.

Gundale MJ, Pauchard A, Langdon B, Peltzer DA, Maxwell BD, Nuñez MA 2014. Can model species be used to advance the field of invasion ecology? Biological Invasions 16: 591-607.

Howell CJ, McAlpine KG 2016. Native plant species richness in non-native Pinus contorta forest. New Zealand Journal of Ecology 40(1).

Hughes RF, Uowolo AL, Togia TP 2012. Recovery of native forest after removal of an invasive tree, Falcataria moluccana, in American Samoa. Biological Invasions 14: 1393-1413.

Husheer SW, Robertson AW 2005. High-intensity deer culling increases mountain beech seedling growth in New Zealand. Wildlife Research 32: 273-280.

Husheer SW, Coomes DA, Robertson AW 2003. Long-term influences of introduced deer on the composition and structure of New Zealand Nothofagus forests. Forest Ecology and Management 181: 99-117.

Kessler CC 2002. Eradication of feral goats and pigs and consequences for other biota on Sarigan Island, Commonwealth of the Northern Mariana Islands. In: Veitch, CR, Clout, MN eds Turning the tide: the eradication of invasive species. Proceedings of the International Conference on Eradication of Island Invasives, Species Survival Commission No. 27. Gland, Switzerland and Cambridge, UK, IUCN - The World Conservation Union. Pp. 132-140.

Kettenring KM, Adams CR 2001. Lessons learned from invasive plant control experiments: a systematic review and meta-analysis. Journal of Applied Ecology 48: 970-979.

King CM 2005. The handbook of New Zealand mammals. 2nd edn. Melbourne, Oxford University Press.

Korhonen L, Korhonen KT, Stenberg P, Maltamo M, Rautiainen M 2007. Local models for forest canopy cover with beta regression. Silva Fennica 41: 671-685.

Lamarque LJ, Delzon S, Lortie CJ 2011. Tree invasions: a comparative test of the dominant hypotheses and functional traits. Biological Invasions 13: 1969-1989.

LatifZA, Blackburn GA2010. The effects of gap size on some microclimate variables during late summer and autumn in a temperate broadleaved deciduous forest. International Journal of Biometeorology 54: 119-129.

Ledgard N, Davis M 2004. Restoration of mountain beech (Nothofagus solandri var. cliffortioides) forest after fire. New Zealand Journal of Ecology 28: 125-135.

Ledgard N, Norton D 2008. The impact of browsing on wilding conifers in the South Island high country. New Zealand Journal of Forestry 52: 29-34.

Lemenih M, Gidyelew T, Teketay D 2004. Effects of canopy cover and understory environment of tree plantations on richness, density and size of colonizing woody species in southern Ethiopia. Forest Ecology and Management 194: 1-10.

LINZ 2015. Land Information of New Zealand website. http:// www.linz.govt.nz/data/geodetic-services (accessed 7 October 2015).

Loh RK, Daehler CC 2007. Influence of invasive tree kill rates on native and invasive plant establishment in a Hawaiian forest. Restoration Ecology 15: 199-211.

Loh RK, Daehler CC 2008. Influence of woody invader control methods and seed availability on native and invasive species establishment in a Hawaiian forest. Biological Invasions 10: 805-819.

Martin TG, Wintle BA, Rhodes JR, Kuhnert PM, Field SA, Low-Choy SJ, Tyre AJ, Possingham HP 2005. Zero tolerance ecology: improving ecological inference by modelling the source of zero observations. Ecology Letters 8: 1235-1246.

McAlpine KG, Timmins SM, Westbrooke I 2009. Bone-seed (Chrysanthemoides monilifera ssp. monilifera) invasion effects on native regeneration in New Zealand coastal plant communities. New Zealand Journal of Ecology 33: 72-82.

Nakagawa S, Schielzeth H 2013. A general and simple method for obtaining $R^{2}$ from generalized linear mixed-effects models. Methods in Ecology and Evolution 4: 133-142.

New Zealand Wilding Conifer Management Group 2014. The right tree in the right place. New Zealand Wilding Conifer Management Strategy 2015-2030. Wellington, Ministry for Primary Industries. http://www.wildingconifers.org. nz/ (accessed 7 October 2015).

Onaindia M, Ametzaga-Arregi I, San Sebastián M, Mitxelena A, Rodríguez-Loinaz G, Peña L, Alday JG 2013. Can understorey native woodland plant species regenerate 
under exotic pine plantations using natural succession? Forest Ecology and Management 308: 136-144.

Ostertag R, Cordell S, Michaud J, Cole TC, Schulten JR, Publico KM, Enoka JH 2009. Ecosystem and restoration consequences of invasive woody species removal in Hawaiian lowland wet forest. Ecosystems 12: 503-515.

Overdyck E, Clarkson BD, Laughlin DC, Gemmill CEC 2013. Testing broadcast seeding methods to restore urban forests in the presence of seed predators. Restoration Ecology 21: 763-769.

Palmer SCF, TruscottAM 2003. Browsing by deer on naturally regenerating Scots pine (Pinus sylvestris L.) and its effects on sapling growth. Forest Ecology and Management 182: 31-47.

Paul TSH, Ledgard NJ 2009. Vegetation succession associated with wilding conifer removal. New Zealand Plant Protection 62: 374-379.

R Core Team 2015. R: A language and environment for statistical computing. R Foundation for Statistical Computing, Vienna, Austria. URL http://www.R-project. org/.

Richardson DM, Rejmánek M2004. Conifers as invasive aliens: a global survey and predictive framework. Diversity \& Distributions 10: 321-331.

Richardson DM, Williams PA, Hobbs RJ 1994. Pine invasions in the southern hemisphere: determinants of spread and invadability. Journal of Biogeography 21: 511-527.

Richardson DM, Hui C, Nuñez MA, Pauchard A 2014. Tree invasions: patterns, processes, challenges and opportunities. Biological Invasions 16: 473-481.

Riegel GM, Miller RF, Krueger WC 1995. The effects of aboveground and belowground competition on understory species composition in a Pinus ponderosa forest. Forest Science 41: 864-889.

Ritter E, Dalsgaard L, Einhorn KS 2005. Light, temperature and soil moisture regimes following gap formation in a semi-natural beech-dominated forest in Denmark. Forest Ecology and Management 206: 15-33.

Rodriguez L 2006. Can invasive species facilitate native species? Evidence of how, when, and why these impacts occur. Biological Invasions 8: 927-939.

Rogers GM 1994. North Island seral tussock grasslands 1. Origins and land-use history. New Zealand Journal of Botany 32: 271-286.

Rundle PW, Dickie IA, Richardson DM 2014. Tree invasions into treeless areas: mechanisms and ecosystem processes. Biological Invasions 16: 663-675.

Shiels AB 2011. Frugivory by introduced black rats (Rattus rattus) promotes dispersal of invasive plant seeds. Biological Invasions 13: 781-792.

Spear D, Chown SL 2009. Non-indigenous ungulates as a threat to biodiversity. Journal of Zoology 279: 1-17.

Svriz M, Damascos M, Zimmermann H, Hensen I 2013. The exotic shrub Rosa rubiginosa as a nurse plant. Implications for the restoration of disturbed temperate forests in Patagonia, Argentina. Forest Ecology and Management 289: 234-242.

van Wilgen BW, Richardson DM 2012. Three centuries of managing introduced conifers in South Africa: Benefits, impacts, changing perceptions and conflict resolution. Journal of Environmental Management 106: 56-68.

Vázquez DP 2002. Multiple effects of introduced mammalian herbivores in a temperate forest. Biological Invasions 4: 175-191.
Wakibara JV, Mnaya BJ 2002. Possible control of Senna spectabilis (Caesalpiniaceae), an invasive tree in Mahale Mountains National Park, Tanzania. Oryx 36: 357-363.

Wardle DA, Barker GM, Yeates GW, Bonner KI, Ghani A2001. Introduced browsing mammals in New Zealand natural forests: aboveground and belowground consequences. Ecological Monographs 71: 587-614.

Wardle J 1984. The New Zealand beeches: ecology, utilisation and management. Christchurch, New Zealand Forest Service.

Westoby M 1984. The self-thinning rule. Advances in Ecological Research 14: 167-225.

Widenmaier KJ, Strong WL 2010. Tree and forest encroachment into fescue grasslands on the Cypress Hills plateau, southeast Alberta, Canada. Forest Ecology and Management 259: 1870-1879.

Williams PA 2011. Secondary succession through nonnative dicotyledonous woody plants in New Zealand. New Zealand Natural Sciences 36: 73-91.

Williams PA, Karl BJ, Bannister P, Lee WG 2000. Small mammals as potential seed dispersers in New Zealand. Austral Ecology 25: 523-532.

Wilmshurst JM, Anderson AJ, Higham TF, Worthy TH 2008. Dating the late prehistoric dispersal of Polynesians to New Zealand using the commensal Pacific rat. Proceedings of the National Academy of Sciences (USA) 105: 7676-7680.

Wilson DJ, Lee WG, Webster RA, Allen RB 2003. Effects of possums and rats on seedling establishment at two forest sites in New Zealand. New Zealand Journal of Ecology 27: $147-155$.

Wilson HD 1994. Regeneration of native forest in Hinewai Reserve, Banks Peninsula. New Zealand Journal of Botany 32: 373-383.

Wotton DM, McAlpine KG 2013. Predicting native plant succession through woody weeds in New Zealand. DOC Research and Development Series 336. Wellington, Department of Conservation. $28 \mathrm{p}$.

Wotton DM, McAlpine KG 2015. Seed dispersal of fleshyfruited environmental weeds in New Zealand. New Zealand Journal of Ecology 39: 155-169.

Wright DM, Tanentzap AJ, Flores O, Husheer SW, Duncan RP, Wiser SK, Coomes DA 2012. Impacts of culling and exclusion of browsers on vegetation recovery across New Zealand forests. Biological Conservation 153:64-71.

Yang L, Liu N, Ren H, Wang J 2009. Facilitation by two exotic Acacia: Acacia auriculiformis and Acacia mangium as nurse plants in South China. Forest Ecology and Management 257: 1786-1793.

Zavaleta ES, Hobbs RJ, Mooney HA 2001. Viewing invasive species removal in a whole-ecosystem context. Trends in Ecology \& Evolution 16: 454-459.

Zerbe S 2002. Restoration of natural broad-leaved woodland in Central Europe on sites with coniferous forest plantations. Forest Ecology and Management 167: 27-42.

Editorial board member: Deb Wilson

Received 26 March 2015; accepted 5 October 2015 